\title{
The State of the Welfare State
}

\author{
Unemployment, Labor Market Policy, and Inequality in the
}

Age of Workfare

David Rueda

Since its emergence, the welfare state has been profoundly connected to the protection of people from labor market risks. In the words of Peter Baldwin, "[s]ocial insurance provided the tools with which to reapportion and moderate the effects of natural and manmade misfortune." This article explores the question of whether we should assume that the welfare state today remains a powerful buffer between unemployment and inequality. A significant portion of the literature on the comparative political economy of industrialized democracies has traditionally emphasized the existence of cross-national variation. I will argue that the generous welfare state on which many of these widelyaccepted frameworks rest has been transformed. Punitive workfare policies, formulated as conditional systems imposed on recipients of income and unemployment support, have become the norm. These policies are designed both to restrict access to social benefits and to push those receiving them into the labor market, often through filling the least well-paid and protected jobs. ${ }^{2}$

Welfare policy is complex and multi-faceted. The paragraph above makes clear that I have a particular dimension of the welfare state in mind: labor market policy. This emphasis is justified for three reasons. First, dealing with the labor market (whether by promoting employment or by mitigating the effects of unemployment) is one of the most redistributive roles of the welfare state. The generosity of labor market policy is targeted at a particularly vulnerable portion of the population and, unlike other more general policies of the welfare state, can therefore have significant effects over the distribution of income. ${ }^{3}$ Second, it is a dimension that is essential to some influential theoretical frameworks exploring the political economy of industrialized democracies (for example, those emphasizing worlds of welfare, varieties of capitalism, or risk and redistribution). Third, unemployment is perhaps the most dramatic (and most politically momentous) consequence of the present crisis. It is important to explore the role of labor market policy in limiting its effects. 
Scholars have underemphasized the significance of the welfare state changes I will explore below, particularly in relation to the effects of unemployment on inequality. This is surprising given the historical importance of labor market policy as an instrument for redistribution and insurance.

\section{Theorizing Unemployment, the Welfare State and Inequality}

There are two outcomes of interest to the arguments in this article: market and disposable income inequality. Market income inequality concerns all market sources of income (earnings as well as self-employment and capital income), and disposable income inequality includes taxes and transfers. The first effect of unemployment on inequality works through its influence on market income. One of the main insights of the literature on labor market segmentation is that unskilled, low-paid workers are more readily substitutable than skilled, high-paid workers and consequently that their bargaining position is more immediately and more adversely affected by unemployment. ${ }^{4}$ The rate of unemployment reflects the overall demand for labor, and low levels of unemployment strengthen workers' bargaining power vis-à-vis employers. Since unskilled/low-paid workers are more readily substitutable than skilled/high-paid workers, their bargaining position is therefore more immediately and more adversely affected by unemployment. By this logic, high unemployment contributes to wage dispersion.

It is not controversial to propose a second effect of unemployment on disposable income inequality. The reason for this is very direct: to the extent that the unemployed receive benefits that are lower than the wage they would receive if they were employed (or receive no benefits at all), an economy with large numbers of unemployed people will have lower incomes at the bottom of the distribution than an economy with no unemployment. As a majority of households rely on earnings for their income, unemployment usually represents a decline in disposable income.

There are two potential roles for the welfare state regarding unemployment-led inequality; the first one concerns its effects on market income and the second one on disposable income. Starting with the second one, the direct role of the welfare state in influencing the income losses of the unemployed is quite straightforward. A more generous welfare state will minimize these losses both by having a high replacement rate for lost wages and by covering a large amount of the population under the blanket of social protection. Social benefits provide a way to redistribute wealth to the poor and to insure them against labor market risks. ${ }^{5}$

The welfare state can also affect market income inequality. There are, as I will argue in more detail below, two sides to the labor market policies that characterize the welfare state: a passive one (mostly consisting of unemployment benefits) and an active one (comprising policies to promote employment). Passive labor market policy (PLMP) affects market income inequality through its generosity. High levels of generosity will protect people from unemployment and make them more reluctant to accept low-pay employment. Active labor market policy (ALMP) can promote more and 
better training for those with low skills and therefore promote higher productivity and lower market inequality. If, on the other hand, active labor market policies are punitive and push individuals into low-pay employment, they will increase market income inequality.

I will distinguish between two historical states of welfare: what I will call the decommodifying (or traditional) welfare state and the workfare state. Starting in the 1990s, a new emphasis on activation and conditionality started to dominate the thinking about social policy in most OECD countries. I will analyze in more detail this transformation below, but the main characteristics of the workfare state can be summarized briefly. First, activation is meant to push people into employment (although often this may turn out to be low-pay employment) by reducing the attractiveness of social benefits. Second, attempts are made to develop or strengthen traditional active labor market policies so that benefit recipients are provided with the skills required to be successful when searching for a job.

These fundamental changes in the nature of the welfare state imply a number of hypotheses. First, as suggested above, the influence of unemployment over both market and disposable income inequality is expected to be positive. Unemployment will increase market inequality (through wage competition in low-skill/low-wage work) and will also increase disposable income inequality (since benefits are generally not generous enough to provide full replacement for lost wages).

The second, and more interesting, aspect of the argument relates to the role of welfare policy. In the decommodifying welfare state, welfare policy has a negative direct effect on market income inequality and strong mitigating effects on the influence of unemployment on disposable income inequality. The negative influence on market income inequality is explained by the fact that these labor market policies provide passive and active incentives for high-pay employment and do not push individuals into low-pay employment. The mitigating influence of welfare policy over the effects of unemployment on disposable income inequality is a reflection of the decommodifying welfare state's high benefit generosity. In the traditional welfare state, redistributive policy has a high responsiveness to increases in unemployment.

In the workfare state, on the other hand, the role of welfare policy has changed. The effect of policy on market income inequality has now become more ambiguous. As I will explain in more detail in the next section, labor market policies emphasizing conditionality and activation are meant to push people into employment. To the extent that this has been low-pay employment, there is the potential for an inegalitarian effect over market income. At the same time, the reduction in the generosity of social benefits inherent to the workfare state means that welfare policy is less effective in buffering the inegalitarian effects of unemployment on disposable income. In the workfare state, redistributive policy has lost some of its responsiveness to increases in unemployment.

It is important to emphasize at this point that these hypotheses about the effects of the welfare state are potentially less clear when we consider the relationship between labor market policy and unemployment. By increasing the reservation wage or weakening job search intensity, higher levels of social benefits could increase equilibrium 
unemployment. The positive effects of welfare policy on market and disposable income equality hypothesized above would need to be reconsidered if, at the same time, generosity were correlated with higher unemployment. However, empirical support for the negative effects of social benefits on unemployment has been contested. Nickell and Layard do indeed find a positive effect of benefit generosity on unemployment, and, more specifically, Kenworthy finds the generosity of unemployment benefit replacement rates to be detrimental to employment growth in private-sector consumer services. ${ }^{6}$ Pontusson, on the other hand, finds this relationship not to be immediately apparent. ${ }^{7}$ Bradley and Stephens find that while the generosity of long-duration benefits has negative effects on employment, the generosity of short-duration benefits has positive effects. ${ }^{8}$

In practical terms, this means that the arguments summarized in the previous paragraphs make it necessary to explore three questions. The first and preliminary one is whether welfare state generosity is associated with higher levels of unemployment. The second question concerns the effects of labor market policy on market income inequality (has it become less egalitarian in the workfare state?). The third question relates to the effectiveness of labor market policy in serving as a buffer between unemployment and disposable income inequality (has the responsiveness of redistribution to unemployment decreased in the workfare state?).

\section{Welfare to Workfare 9}

Starting in the 1990s, arguments emphasizing the need for activation (or social investment) started to dominate the debate about the welfare state in industrialized democracies. The perception, in the words of Frank Vandenbroucke, former Minister for Social Affairs and Pensions in Belgium, was that "the traditional welfare state is, in a sense, predominantly a passive institution. Only once there has been a bad outcome is the safety net spread. It is surely much more sensible for an active state to respond to old and new risks and needs by prevention." from consumption and maintenance-oriented programs to those that invest in people and enhance their capacity to participate in the productive economy."11

This new emphasis on activation was a response in part to the criticism of the traditional welfare state as too focused on male breadwinners and ill-equipped to deal with the transition to post-industrialism, with new risks emerging from the social and demographic transformation of families, or with the demands of the "knowledge economy." 12 The traditional welfare state is perceived as a way to repair the damage associated with changing employment conditions and family patterns, while activation is presented as a way to avoid these risks through investment in human capital development. ${ }^{13}$

The starting point for activation initiatives is also the idea that passive labor market policies can produce benefit dependency and increase unemployment. "In this sense," in the words of Morel et al., "the social investment perspective shares with neoliberalism the notion that social spending should be directed towards activating people in order to allow individuals and families to maintain responsibility for their 
wellbeing via market incomes, rather than towards passive benefits."14 While the social investment model retains the neoliberal focus on activation, it offers us an ambiguous (as it will be shown below) promise that, if accompanied by investments in human capital, activation will promote "quality jobs."

In policy terms, one "demanding" aspect of activation has therefore involved limiting social benefits by either reducing their generosity or making eligibility more difficult. Receiving social benefits "increasingly depends on job search activities, acceptance of available job offers or participation in active labour market policy schemes." 15 In this respect, "the core element of activation is the removal of options for labour market exit and unconditional benefit receipt by members of the working-age population." ${ }^{\text {" }} \mathrm{A}$ second aspect, what Eichhorst and Konle-Seidl call the "enabling" side of activation, attempts to develop or strengthen active labor market policies like job search assistance, subsidized employment, training programs, and "making work pay" initiatives designed to facilitate entry into the labor market by topping up low-pay jobs. ${ }^{17}$

For this article's argument, the demanding side of workfare is crucial. I argue that activation and conditionality have represented a move towards the recommodification of the welfare state. Recommodification is, in this context, the opposite of EspingAndersen's celebrated concept. For Esping-Andersen, the nature of the welfare state was fundamentally defined by the levels of decommodification it accomplished. Decommodification meant the emancipation of the individual from market dependence by promoting the provision of social services as a matter of right. ${ }^{18}$ It is clear then that activation, by reducing social benefits and pushing people into work, represents recommodification. Far from emancipating, its explicit objectives are to make the individual more dependent on the market and the provision of benefits dependent on deservingness, not rights. It is also clear that this dimension of activation harks back to some of the defining characteristics of the liberal model. Already in his 1995 study, King describes the British and American approach to work-welfare as epitomized historically by "the priorities of excluding the undeserving from public assistance, distinguishing them from worthy recipients, and imposing work-requirements on beneficiaries." 19

The increasing importance of workfare is a phenomenon common to all industrialized democracies. There are several reasons for this. Economic changes (like the shift from manufacturing to services or the emergence of insider-outsider differences $)^{20}$ and demographic ones (new social risks emerging from the ageing of the population, the decline of traditional family structures, and declining birthrates) ${ }^{21}$ present new challenges for the welfare state while globalization and (for some countries) European integration limit the degrees of freedom enjoyed by governments. ${ }^{22}$ Until the $1980 \mathrm{~s}$, many OECD countries had relied on policies to reduce labor supply to combat unemployment. These included early retirement initiatives and the use of incapacity and sickness benefits as substitutes for other social benefits. Early retirement schemes have been particularly popular in continental Europe. ${ }^{23}$ However, in the era of permanent fiscal austerity, solutions relying on the promotion of labor market exit became much more difficult. Cost containment emerged as a top priority in all industrialized democracies, even if national strategies to address this goal have been quite diverse. ${ }^{24}$ 
Measuring the Workfare State As the section above makes clear, there are two defining characteristics of the workfare state: conditionality and activation. The objective of this article is to explore the influence of the workfare state on the relationship between unemployment and inequality. For this purpose, summary measures for the two distinct dimensions of the workfare state are needed.

Conditionality essentially makes social benefits less generous and more difficult to obtain. This demanding side of the workfare state is best captured by a measure of benefit generosity. Conceptualizing generosity, however, is not straightforward. It is common to assess the importance of the welfare state by looking at the level of social policy as a percentage of GDP, but this measure is limited in its ability to capture welfare state generosity. Its most important weakness concerns the fact that it focuses exclusively on the supply of social policy and ignores the demand side. In this respect, Clayton and Pontusson convincingly argue that "measuring the size of the welfare state in terms of social spending as a percentage of GDP, as virtually all of the literature does, is problematic because such measures fail to take account of changes in societal welfare needs. ${ }^{25}$ In this article, I follow the lead of a number of other authors by measuring benefit generosity as the ratio of labor market policy to GDP over the ratio of the unemployed to the labor force. ${ }^{26}$ This seems a reasonable way to assess the generosity of the welfare state: for example, when unemployment-related transfers rise faster as a proportion of the total size of the economy than the unemployment rate, this measure of benefit generosity will increase.

Table 1 PLMP and ALMP Generosity

Demanding Workfare

(unemployment benefits as \% of GDP over harmonized unemployment rate as $\%$ of labor force)

\begin{tabular}{|c|c|c|c|c|c|c|c|c|c|c|}
\hline & $1985-1989$ & $1990-1994$ & 1995-1999 & $2000-2005$ & $2005-2009$ & 1985-1989 & 1990-1994 & 1995-1999 & $2000-2005$ & $2005-2009$ \\
\hline Australia & 0.13 & 0.15 & 0.14 & 0.12 & 0.10 & 0.03 & 0.05 & 0.06 & 0.06 & 0.07 \\
\hline Austria & & 0.41 & 0.35 & 0.31 & 0.30 & & 0.09 & 0.11 & 0.14 & 0.16 \\
\hline Belgium & 0.32 & 0.37 & 0.28 & 0.30 & 0.28 & 0.13 & 0.15 & 0.13 & 0.14 & 0.16 \\
\hline Canada & 0.19 & 0.19 & 0.12 & 0.10 & 0.10 & 0.06 & 0.06 & 0.05 & 0.05 & 0.05 \\
\hline Denmark & 0.70 & 0.60 & 0.60 & 0.51 & 0.40 & 0.19 & 0.17 & 0.31 & 0.38 & 0.34 \\
\hline Finland & 0.29 & 0.31 & 0.24 & 0.22 & 0.22 & 0.17 & 0.15 & 0.10 & 0.10 & 0.12 \\
\hline France & 0.16 & 0.17 & 0.14 & 0.18 & 0.15 & 0.08 & 0.10 & 0.11 & 0.13 & 0.10 \\
\hline Germany & & 0.33 & 0.26 & 0.24 & 0.17 & & 0.20 & 0.14 & 0.14 & 0.10 \\
\hline Greece & 0.05 & 0.05 & 0.04 & 0.04 & 0.05 & 0.03 & 0.03 & 0.04 & & \\
\hline Ireland & 0.19 & 0.19 & 0.20 & 0.19 & 0.20 & 0.07 & 0.08 & 0.13 & 0.18 & 0.12 \\
\hline Italy & & 0.11 & 0.07 & 0.07 & 0.12 & & & & 0.08 & 0.07 \\
\hline Japan & 0.11 & 0.14 & 0.12 & 0.09 & 0.08 & & 0.14 & 0.08 & 0.05 & 0.06 \\
\hline Luxembourg & 0.31 & 0.26 & 0.24 & 0.18 & 0.13 & 0.14 & 0.07 & 0.06 & 0.10 & 0.10 \\
\hline Netherlands & 0.46 & 0.50 & 0.52 & 0.54 & 0.41 & 0.20 & 0.25 & 0.28 & 0.43 & 0.30 \\
\hline New Zealand & 0.21 & 0.18 & 0.19 & 0.18 & 0.08 & 0.18 & 0.09 & 0.09 & 0.08 & 0.10 \\
\hline Norway & 0.18 & 0.21 & 0.18 & 0.18 & 0.15 & 0.17 & 0.17 & 0.23 & 0.19 & 0.19 \\
\hline Portugal & 0.04 & 0.12 & 0.13 & 0.17 & 0.13 & 0.04 & 0.11 & 0.09 & 0.11 & 0.07 \\
\hline Spain & 0.04 & 0.12 & 0.13 & 0.17 & 0.13 & 0.04 & 0.04 & 0.03 & 0.07 & 0.08 \\
\hline Sweden & 0.36 & 0.42 & 0.23 & 0.19 & 0.11 & 0.86 & 0.59 & 0.27 & 0.24 & 0.17 \\
\hline Switzerland & 0.29 & 0.32 & 0.33 & 0.24 & 0.20 & 0.30 & 0.18 & 0.20 & 0.21 & 0.17 \\
\hline United Kingdom & 0.11 & 0.11 & 0.07 & 0.05 & 0.04 & 0.05 & 0.04 & 0.04 & 0.07 & 0.06 \\
\hline United States & 0.07 & 0.07 & 0.05 & 0.07 & 0.08 & 0.04 & 0.03 & 0.04 & 0.03 & 0.03 \\
\hline
\end{tabular}

Enabling Workfare

(active labor market policy as \% of GDP over harmonized unemployment rate as \% of labor force) 
Table 1 summarizes demanding workfare (measured as unemployment benefits as percent of GDP over the harmonized unemployment rate ${ }^{27}$ ) for the OECD countries. ${ }^{28}$ The high degree of cross-national variation in the table is best illustrated by dividing the countries into three groups (not really coinciding with the three usual varieties of capitalism, or worlds of welfare capitalism). The Mediterranean (France, Greece, Italy, Portugal, and Spain), most of the liberal economies (Australia, Canada, Ireland, New Zealand, UK, and USA), and Japan belong to the group characterized by low levels of benefit generosity. All these countries spend averages of less than 0.20 percent of GDP per 1 percent of unemployed. The group characterized by intermediate levels of benefit generosity comprises a number of non-Mediterranean continental countries (Belgium, Germany, Luxembourg, and Switzerland) and two Scandinavian ones (Finland and Norway). These countries spend averages of more than 0.20 percent but less than around 0.35 percent of GDP per 1 percent of unemployed. The final group is made up of Austria, Denmark, and the Netherlands. They spend the highest average amounts on benefits per 1 percent of unemployed (more than 0.35 percent of GDP). Sweden, at different times, belongs to all groups.

This cross-national variation is interesting, but the arguments about activation presented above are also concerned with temporal variation. Conditionality is a process that has transformed the welfare state in these countries, making unemployment benefits less generous. Table 1 presents evidence for this. If we understand a move towards more demanding welfare to be captured by a reduction in benefit generosity from the 1985-1994 period to the 1995-2009 period, fourteen countries in Table 1 clearly experience it. Spending on unemployment benefits as percentage of GDP over percentage of unemployed declines in Australia, Austria, Belgium, Canada, Denmark, Finland, Germany, Japan, Luxembourg, New Zealand, Norway, Sweden, Switzerland, and the UK. This leaves eight countries that have not experienced clear increases in the demanding dimension of welfare. Some of them (Greece, Italy, Portugal, Spain, and the US) have very low levels of generosity that do not really change (except for initial surges in Portugal and Spain). France and Ireland have slightly higher levels of generosity that are also characterized by stability. The most clear exception to the general argument about increasing conditionality is the one country with very high levels of generosity that do not significantly decline over the period of time under analysis (the Netherlands).

The second dimension of the workfare state (activation) relates to its enabling potential and, as mentioned above, to the traditional role of active labor market policies. In this respect, the most straightforward measure for this dimension is the one provided by the OECD. This measure contains all expenditure aimed at the improvement of an individual's chances of finding employment. ${ }^{29}$ As in the previous analysis, I measure the generosity of active labor market policy as the ratio of spending to GDP over the harmonized ratio of the unemployed to the labor force.

The right half of Table 1 summarizes enabling workfare. Using these figures, it is possible once again to divide our countries into three groups. In fact, comparing the two halves in Table 1, it is impossible not to notice the similarities. When looking at cross-national differences, the levels of generosity in unemployment benefits seem 
highly correlated with the levels of generosity in active labor market policy. There is once again a group characterized by low levels of ALMP generosity comprising most of the Mediterranean and liberal economies. Australia, Austria (except 2005-2009), Belgium (except 2005-2009), Canada, France, Greece, Italy, Japan, Luxembourg, New Zealand (except 1985-1989), Portugal, Spain, the UK, and the USA belong to this group. All these countries spend an average of less than 0.15 percent of GDP per 1 percent of unemployed. There is again a group characterized by intermediate levels of ALMP generosity including Scandinavian, liberal, and non-Mediterranean continental countries (Finland, Germany, Ireland, and Norway). These countries spend an average of more than 0.15 percent in some periods but always less than 0.20 percent of GDP per 1 percent of unemployed. The final group is made up of Denmark, the Netherlands, Sweden, and Switzerland. They spend the highest average amounts on ALMP per 1 percent of unemployed (often more than 0.25 percent of GDP, and never below 0.15 percent).

While in the left half of Table 1, a significant number of countries had experienced clear increases in the demanding side of workfare, the picture is less consistent when looking at the enabling side of workfare. Comparing the levels of active labor market policy generosity from the 1985-1994 period to the 1995-2009 period, only six countries have experienced increases in the levels of ALMP per 1 percent unemployed (Australia, Austria, Denmark, Ireland, the Netherlands, and Norway). Moreover, in most of these countries, the changes seem too small to offset the increasing conditionality of unemployment benefits. In some countries, the levels of generosity remain more or less constant (Belgium, France, Greece, Portugal, and Spain). And in many countries, the increase in conditionality shown in Table 1 is in fact matched by a decrease in generosity (Canada, Finland, Germany, Japan, Luxembourg, New Zealand, Sweden, and Switzerland all experience declines in ALMP generosity).

The general decrease in the generosity of the welfare state suggested by Table 1 has been noted by a number of observers. ${ }^{30}$ However, it is possible to provide more systematic evidence for this decline. It is also possible to illustrate the lack of a general increase in active labor market policy generosity. I run two simple regression models in which the generosity of unemployment benefits (or of active labor market policy) is determined by just two factors: a time trend and country fixed effects. Intuitively, these models will produce an average for the different within-country slopes capturing the effects of time. I run the following models:

$$
Y_{i t}=\beta_{1} T_{t}+N_{i}+\varepsilon_{i t}
$$

where $Y_{i t}$ represents the levels of generosity in country $i$ at time $t, T_{t}$ is the time trend (yearly data), $\beta_{1}$ is the slope capturing the effect of time, $N_{i}$ are country fixed effects, and $\varepsilon_{i t}$ denotes the errors.

Table 2 reflects the decreasing generosity of unemployment benefits in the OECD. It shows that the passing of each year was significantly associated (at better than the 99 percent confidence level) with a decrease of 0.004 percent of GDP per 1 percent 
Table 2 Effects of Time (1985-2009).

\begin{tabular}{lcc}
\hline & $\begin{array}{c}\text { Demanding } \\
\text { Workfare }\end{array}$ & $\begin{array}{l}\text { Enabling } \\
\text { Workfare }\end{array}$ \\
\hline Intercept & $0.254 * * *$ & $0.151^{* * *}$ \\
Time Trend & $(0.005)$ & $(0.008)$ \\
& $-0.004 * * *$ & $-0.001 * *$ \\
& $(0.000)$ & $(0.001)$ \\
$\mathrm{N}$ & 529 & 489 \\
\hline
\end{tabular}

Notes: OLS results with country fixed effects. Numbers are estimated coefficients; numbers in parentheses are standard errors. * if significant at $90 \%$ level; $* *$ if significant at $95 \%$ level; $* * *$ if significant at $99 \%$ level. Country dummy estimates not reported, available from the author.

unemployed. More importantly, the results in Table 2 also show that, if anything, the average generosity of active labor market policy has decreased in the countries in our sample. The table shows that each additional year was significantly associated (at better than the 95 percent confidence level) with an average decrease of 0.001 percent of GDP per 1 percent unemployed.

The analysis of Tables 1 and 2 produces two main conclusions. First, there is a general and significant decline in passive labor market generosity (i.e., an increase in the demanding side of workfare). ${ }^{31}$ This is not necessarily surprising, but it is illustrated in a convincing and straightforward way in the tables. Second, and more importantly, although some countries experience increases in active labor market policy generosity, these increases are neither substantial enough to compensate for the decline in unemployment benefits nor general enough when looking at the countries in our sample. In fact, the only systematic change in these OECD countries is a slight decline in active labor market policy generosity (certainly not an increase in the enabling side of workfare). It is still the case that some countries are more "decommodifying" than others (even in the age of workfare) and that these countries tend to combine generosity of unemployment benefits and of ALMPs. However, if the social investment model is predicated on increasing the conditionality of passive measures while increasing the resources dedicated to active measures, it is unclear that it is one that has been widely adopted among industrialized democracies since the mid-1990s.

\section{Unemployment, the Welfare State, and Inequality}

The arguments above make it necessary to explore three questions in two different periods of time distinguished by the increasing importance of workfare. These questions concern labor market policy generosity, unemployment, and inequality. 
Labor Market Policy and Unemployment I explore the effects of both the decommodifying welfare state (the period up to the mid-1990s) and the workfare state on unemployment. I use the same measures of generosity described above and the harmonized unemployment rate. To make these data compatible with the inequality measures to be used in subsequent sections, all variables in the analysis are averages. The decommodifying welfare state period contains three time-period averages: mid-1980s (from 1985 to 1986), 1990 (from 1989 to 1991), and mid1990s (from 1994 to 1996). The workfare state period also contains three timeperiod averages: 2000 (from 1999 to 2001), mid-2000s (from 2004 to 2006), and late-2000s (from 2007 to 2009). ${ }^{32}$ Compatibility with inequality data also means that the sample of countries is reduced to twelve: Canada, Denmark, Finland, Germany, Luxembourg, the Netherlands, New Zealand, Norway, Portugal, Sweden, UK, and USA.

I produce a simple regression model estimating the effects of labor market policy generosity on unemployment while controlling for country fixed effects. Again, intuitively, this model will produce an average for the different within-country slopes capturing the effects of welfare state generosity on unemployment. I run the following model:

$$
Y_{i t}=\beta_{1} X_{i t}+N_{i}+\varepsilon_{i t}
$$

where $Y_{i t}$ represents the levels of harmonized unemployment in country $i$ at time $t^{33}$ $X_{i t}$ is welfare policy generosity, $\beta_{1}$ is the slope capturing the effect of generosity, $N_{i}$ are country fixed effects, and $\varepsilon_{i t}$ denotes the errors.

Table 3 Determinants of Unemployment

\begin{tabular}{|c|c|c|c|c|c|c|}
\hline & \multicolumn{3}{|c|}{$\begin{array}{l}\text { Decommodifying Welfare State } \\
(1985-1996)\end{array}$} & \multicolumn{3}{|c|}{$\begin{array}{l}\text { Workfare State } \\
(1999-2009)\end{array}$} \\
\hline & (1) & (2) & (3) & (4) & (5) & (6) \\
\hline Intercept & $\begin{array}{l}11.000 * * * \\
(1.268)\end{array}$ & $\begin{array}{c}11.829 * * * \\
(2.385)\end{array}$ & $\begin{array}{l}9.129 * * * \\
(0.732)\end{array}$ & $\begin{array}{l}7.262 * * * \\
(0.846)\end{array}$ & $\begin{array}{l}6.589 * * * \\
(0.880)\end{array}$ & $\begin{array}{l}7.818 * * * \\
(0.672)\end{array}$ \\
\hline LMP & $-10.213 * * *$ & & & -3.906 & & \\
\hline Generosity & (2.819) & & & $(2.413)$ & & \\
\hline Passive LMP & & $-19.916^{* *}$ & & & -3.982 & \\
\hline Generosity & & $(8.925)$ & & & $(4.448)$ & \\
\hline Active LMP & & & $-15.059 * * *$ & & & $-12.642 * * *$ \\
\hline Generosity & & & $(3.840)$ & & & (4.349) \\
\hline $\mathrm{N}$ & 35 & 35 & 35 & 35 & 36 & 35 \\
\hline
\end{tabular}

Notes: OLS results with country fixed effects. Numbers are estimated coefficients; numbers in parentheses are standard errors. * if significant at $90 \%$ level; $* *$ if significant at $95 \%$ level; $* * *$ if significant at $99 \%$ level. Country dummy estimates not reported, available from the author. 
Table 3 presents little evidence in favor of the argument that welfare state generosity promoted high levels of unemployment before 1995 . When looking at the decommodifying welfare state (columns 1-3), a negative relationship between labor market policy generosity and unemployment existed within countries. Column (1) on Table 3 shows that, on average, a one-unit increase in generosity was associated with a more than 10 percent decrease in unemployment in the countries in our sample. This relationship was significant at more than the 99 percent level of confidence. To illustrate, the average level for the decommodifying welfare state period was 0.43 percent of GDP dedicated to active and passive labor market policy per 1 percent unemployed. This was also the level of Germany in the mid-1990s. The average level of harmonized unemployment, on the other hand, was around 6 percent of the labor force. If labor market policy generosity increased from the average level in the period to that of Denmark in the mid-90s ( 0.87 percent of GDP per 1 percent unemployed), unemployment would decrease to 1.6 percent of the labor force. The relationship between these variables seems to go in the direction opposite to that which was feared by critics of the welfare state: a more generous welfare state seems to promote lower levels of unemployment. ${ }^{34}$

Table 3 also provides some evidence about the separate effects of active and passive labor market policy generosity. Still focusing on within-country variation during the decommodifying welfare state period, columns (2) and (3) in Table 3 show that both active and passive labor market policy generosity have negative effects on unemployment. On average, a one-unit increase in passive labor market policy is significantly correlated (at better than a 95 percent confidence level) with an almost 20 percent decrease in unemployment. A similar increase in active labor market policy generosity is also significantly correlated (this time at better than a 99 percent confidence level) with more than a 15 percent decrease in unemployment.

The first change when exploring the workfare state results in Table 3 (columns 4-6) is that labor market policy generosity is an insignificant determinant of unemployment in the more recent period. While labor market policy in the decommodifying welfare state had significantly negative effects on unemployment, they do not in the workfare state. Column (4) in Table 3 shows that, on average, the effect of a one-unit increase in welfare policy generosity is undistinguishable from zero. Table 3 , however, provides some evidence about the separate effects of active labor market policy generosity in the workfare state that is similar to those for the decommodigying welfare state. While column (5) shows the effects of passive labor market policy generosity to be as insignificant as the general effects in column (4), the effects of active labor market policy generosity in column (6) are negative and statistically significant at better than the 99 percent confidence level.

Table 3 then suggests that the employment promotion effects of labor market policy have declined considerably. Not only has the transformation from welfare to workfare made the effects of passive labor market insignificant, but the effects of active labor market policy are also weaker. It is clear, nevertheless, that the main concerns of welfare state critics are still unfounded. The generosity of the welfare state 
is still not correlated with increases in unemployment. Higher reservation wages do not seem to price out low-skilled workers. At worst, the relationship is insignificant. The estimates in Table 3 also indicate that active labor market policy promotes employment (even in the era of the workfare state). This article's second question, however, concerns the relationship between welfare policy generosity and market income inequality. In other words, do the decommodifying welfare state and the workfare state push people into low- or high-pay employment?

\section{The Welfare State and Market Income Inequality}

To explore the relationship between labor market generosity and market income inequality, I estimate a regression model similar to the one in the previous section. ${ }^{35}$ I use Gini coefficients based on equivalized household market income provided by the OECD. ${ }^{36}$

A number of authors have noted that pensions play a major role in overall income redistribution in OECD countries. ${ }^{37}$ The arguments in this article concern the role of the welfare state as a determinant of market income inequality and as a buffer between unemployment and disposable income inequality. These two effects are hypothesized to affect the working-age population. Including pensioners would distort the analysis so the data used in this article refer to market income inequality among working-age households (ages eighteen to sixty-five).

Table 4 Determinants of Market Income Inequality

\begin{tabular}{|c|c|c|c|c|c|c|}
\hline & \multicolumn{3}{|c|}{$\begin{array}{l}\text { Decommodifying Welfare State } \\
(1985-1996)\end{array}$} & \multicolumn{3}{|c|}{$\begin{array}{l}\text { Workfare State } \\
(1999-2009)\end{array}$} \\
\hline & (1) & (2) & (3) & (4) & (5) & (6) \\
\hline Intercept & $\begin{array}{l}0.422 * * * \\
(0.018)\end{array}$ & $\begin{array}{l}0.429 * * * \\
(0.033)\end{array}$ & $\begin{array}{l}0.407 * * * \\
(0.010)\end{array}$ & $\begin{array}{l}0.421 * * * \\
(0.011)\end{array}$ & $\begin{array}{l}0.419 * * * \\
(0.012)\end{array}$ & $\begin{array}{c}0.426 * * * \\
(0.009)\end{array}$ \\
\hline LMP & $-0.080^{*}$ & & & -0.021 & & \\
\hline Generosity & $(0.039)$ & & & $(0.031)$ & & \\
\hline Passive LMP & & -0.156 & & & -0.035 & \\
\hline Generosity & & $(0.120)$ & & & $(0.060)$ & \\
\hline Active LMP & & & $-0.116^{* *}$ & & & -0.085 \\
\hline Generosity & & & $(0.053)$ & & & $(0.060)$ \\
\hline $\mathrm{N}$ & 31 & 31 & 31 & 35 & 36 & 35 \\
\hline
\end{tabular}

Notes: OLS results with country fixed effects. Numbers are estimated coefficients; numbers in parentheses are standard errors. * if significant at $90 \%$ level; ** if significant at $95 \%$ level; *** if significant at $99 \%$ level. Country dummy estimates not reported, available from the author.

Table 4 suggests that a negative relationship between labor market policy generosity and market income inequality existed in the decommodifying welfare state period. Column (1) in Table 4 shows that, on average, a one-unit increase in labor market policy 
generosity is associated with a 0.08 percent decrease in the Gini coefficient in the countries in our sample; however, this relationship is only significant at the 90 percent level of confidence. More importantly, the separate analysis of passive versus active labor market policy generosity illuminates the nature of this relationship in the decommodifying welfare state period. Column (2) shows that passive labor market policy generosity is an insignificant determinant of market income inequality. The generosity of active labor market policy, however, is shown in Column (3) to be significantly (at better than the 95 percent confidence level) egalitarian. The active policies promoted by the decommodifying welfare state were effective at promoting high-pay jobs. ${ }^{38}$ This is an important finding whose substantive effect can be illustrated as follows. The average level of generosity for the observations in the table's analysis is 0.17 percent of GDP dedicated to active labor market policy per 1 percent unemployed. This is around the level of the Netherlands in the mid-1980s. The average Gini for market income inequality in the sample, on the other hand, is around 0.387 . If active labor market policy generosity were increased from the average level in the sample to that of Sweden in the mid-80s ( 0.73 percent of GDP per 1 percent unemployed), market income inequality would decrease by 17 percent.

There is a significant change again when we compare the effect of labor market policy during the decommodifying welfare state (columns 1 to 3 ) and the workfare state (columns 4 to 6 ) periods. While the decommodifying welfare state promoted a negative relationship between labor market policy generosity and market income inequality within countries (column 1), the workfare state makes this relationship disappear (column 4). Column (3) showed increases in active labor market policy generosity to be significantly correlated with a substantively important decrease in market income inequality. Column (6) shows no such effect. While the active policies promoted by the decommodifying welfare state were effective at promoting high-pay jobs, they are not playing this role in the workfare state.

The relevance of this finding should be emphasized. I will first point out that the findings in Table 4 support other work arguing that the "enabling" side of workfare is not clearly correlated to the creation of "quality jobs." Bonoli shows that active labor market policies have represented more of a continuation of neoliberal workfare policies than a true shift towards upskilling or the promotion of highly-paid jobs. He analyzes the evolution of active measures in six countries (Denmark, Italy, Germany, France, Sweden, and the UK) since the 1950s. When looking at the period from the mid1990 s to the late 2000s, however, he finds ALMPs to be focused mostly on promoting low-skill employment in the service sector. ${ }^{39}$

Second, to go back to one of the previous themes, if workfare means more and better training for those with low skills (as proponents for the social investment model maintain), then it will promote higher productivity and, consequently, lower unemployment and market income inequality. If workfare, on the other hand, means an increase in punitive active labor market policies to push individuals into low-pay employment, then it will increase income inequality while decreasing unemployment. The evidence in tables 3 and 4 suggests that labor market policy used to have the first effect but 
now has more of the second effect. The generosity of active labor market policy promoted higher levels of employment both during the decommodifying welfare state and workfare periods, but only the decommodifying welfare state did so by promoting high-pay employment (and higher market income equality).

\section{The Welfare State, Unemployment, and Redistribution}

Our third question concerns the effectiveness of the welfare state as a buffer between unemployment and disposable income inequality. I will focus on redistribution as the difference between market income inequality and disposable income inequality. ${ }^{40}$ The logic here is straightforward. As explained above, we would expect unemployment to affect earnings inequality (directly, when someone loses his/her job, or through wage competition), while the effects over disposable income inequality should be mitigated by the generosity of the welfare state. The more responsive redistributive policy is to increases in unemployment, the less influential unemployment will be over disposable income inequality.

In order to control for variation in market income inequality among countries and for the effects of unemployment on market income inequality, the measure of redistribution in this article is the reduction in the Gini coefficient from market to disposable income (expressed as a percentage of the Gini for market income). ${ }^{41}$ As in the previous analysis, the data for redistribution used in this article refer to income inequality among working-age households. To illustrate, in Sweden in the mid-1990s, the Gini for market income inequality was 0.374 and the Gini for disposable income inequality was 0.216 . This implies a 42 percent decrease in inequality from market to disposable income, which is the value for redistribution for Sweden in the mid-1990s in the analysis below.

Table 5 presents estimates from a regression model similar to the ones in previous sections. $^{42}$ The results confirm that a positive relationship between unemployment and redistribution existed within countries in the decommodifying welfare state period. ${ }^{43}$ On average, a 1 percent increase in unemployment was matched by a 1.1 percent increase in redistribution in the countries in our analysis during this period. This effect is statistically significant (at better that the 99 percent confidence level) and substantively important. The average level of unemployment in this period was around 6 percent of the labor force. The average level for redistribution, on the other hand, was about 30 percent. This is a level of redistribution roughly equivalent to that of Germany around 1990. According to the estimates in Table 5, an increase in unemployment from the average level in the sample to that of New Zealand around 1990 or Portugal in the mid-1980s (about 9 percent of the labor force) would be matched by an 11 percent increase in redistribution.

Table 5 shows a similar relationship within countries in the workfare state period. On average, a 1 percent increase in unemployment was matched by a 0.9 percent increase in redistribution in the countries in our analysis during this period. It is clear, however, that the redistributive effects of welfare policy have become much weaker 
Table 5 Determinants of Redistribution

\begin{tabular}{lcc}
\hline & $\begin{array}{c}\text { Decommodifying } \\
\text { Welfare State } \\
(1974-1996)\end{array}$ & $\begin{array}{c}\text { Workfare } \\
\text { State } \\
(1999-2009)\end{array}$ \\
\hline Intercept & $\begin{array}{l}(1) \\
\text { 21.956*** }\end{array}$ & $\begin{array}{c}(2) \\
(1.379)\end{array}$ \\
Harmonized & $1.117^{* * *}$ & $(2.121)$ \\
Unemployment & $(0.203)$ & $0.874 * *$ \\
& & $(0.359)$ \\
$\mathrm{N}$ & 37 & 36 \\
\hline Notes: OLS results with country fixed effects. Numbers are estimated \\
coefficients; numbers in parentheses are standard errors. * if significant \\
at 90\% level; ** if significant at 95\% level; *** if significant at 99\% \\
level. Country dummy estimates not reported, available from the author.
\end{tabular}

in the era of workfare. The coefficient for unemployment is both less statistically significant and less substantively important. The smaller coefficient implies that the responsiveness of redistribution to unemployment has decreased by more than 21 percent. While a 3 percent increase in unemployment would be associated with an 11 percent increase in the average redistribution level for the decommodifying welfare state sample (30 percent), in the era of workfare the same increase in unemployment is only associated with less than a 9 percent increase in the same 30 percent level of redistribution.

\section{Conclusion}

Inequality is frequently invoked as an explanation for a number of crucial issues in political science. It is often considered a determinant of processes as diverse as the decline of electoral turnout, ${ }^{44}$ the increase in the support of extreme-right parties, ${ }^{45}$ or the likelihood of political conflict. ${ }^{46}$ Recently, and for good reason, the political causes of inequality have received an increasing amount of attention. Focusing on the American case, Bartels has shown the spectacular increase in inequality over the past thirty-five years to be the product of policy choices in a political system dominated by partisanship and particularly receptive to the preferences of the wealthy. ${ }^{47}$ Hacker and Pierson coincide not only in their appreciation of the attention that policy-makers pay to the rich in America, but also about the fact that politics is the main factor behind inequality (“American politics did it"). ${ }^{48}$

The analysis provided in this article remains a preliminary and illustrative one. A number of factors may affect inequality while also influencing the generosity of the welfare state (slower economic growth, the transition to a post-industrial economy, etc). Only a multivariate analysis with more extensive data would allow us to disentangle systematically the individual effects of these related processes. Nevertheless, I have 
provided some evidence that policy influences inequality in significant ways and that its effects depend on whether we look at the decommodifying welfare state or the workfare state periods. While there has been a general move towards more demanding welfare (i.e., less generous unemployment benefits) in industrialized democracies, there seems to be a much more questionable move towards more enabling workfare (i.e., more generous active policies). More importantly, the role of welfare policy seems to be much less egalitarian in the workfare state era, both regarding market income inequality and redistribution.

The present economic crisis has had and will have dramatic effects on unemployment in most OECD countries. However, it is much less clear that governments have reacted to the extraordinary circumstances brought about by the crisis by increasing the levels of PLMP and ALMP generosity (therefore reversing the recent trend towards workfare). If we were to look at the yearly changes since 2007 contained in the period averages in Table 1, the most remarkable characteristic would be stability. The commitment to mitigating the effects of the crisis on unemployment and the effects of unemployment on poverty seems, at best, weak. Budgetary concerns and fiscal discipline have replaced unemployment as the main goals of governments of all ideologies. ${ }^{49}$

This article makes two main points in an attempt to reverse this increasing apathy towards the implications of the crisis with regards to unemployment. The first one is that labor market policy is an effective tool to promote equality. In the era of the decommodifying welfare state, it was a powerful buffer between unemployment and income inequality. The second one is that by the arrival of the Great Recession in 2007, the welfare state in most OECD countries had gone through a profound change. Since the 1990s, conditionality had transformed social benefits, and labor market policies had become more demanding. An emphasis on enabling activation, on the other hand, had not been adopted equally throughout the OECD. This transformation has important implications for the ability of the welfare state to promote equality. Only by understanding the nature of the workfare state will we be able to assess the likely consequences of this and future crises. This article represents a first step in this process.

\section{NOTES}

Previous versions of this article were presented at the International Conference of Europeanists (2012), the Oxford Institute of Social Policy (Oxford University), the conference on "The Changing Welfare States and the Korean Welfare State at the Crossroads" (Korea University), the Department of Political Science (University of Geneva), and the School of Sociology Seminar Series (University College Dublin). In addition to the participants in these meetings, I would like to thank Lucy Barnes, Pablo Beramendi, Nancy Bermeo, Charlotte Cavaille, Niamh Hardiman, Tim Hicks, Desmond King, Basak Kus, Hyeok Yong Kwon, Johannes Lindvall, Bruno Palier, Georg Picot, Jonas Pontusson, Damian Raess, Philipp Rehm, Martin Seeleib-Kaiser, David Soskice, as well as two anonymous reviewers, for their comments and suggestions. This research was partly supported by the National Research Foundation of Korea (grant number: 2014S1A3A2044032).

1. Peter Baldwin, The Politics of Social Solidarity (New York: Cambridge University Press, 1990), 3.

2. See Desmond King and David Rueda, "Cheap Labor: The New Politics of 'Bread and Roses' in Industrial Democracies," Perspectives on Politics, 6 (June 2008), 279-97. 
3. See, for example, Walter Korpi and Joakim Palme, "New Politics and Class Politics in the Context of Austerity and Globalization: Welfare State Regress in 18 Countries, 1975-95," American Political Science Review, 97 (August 2003), 425-46.

4. James Galbraith, Created Unequal (New York: The Free Press, 1998) and Katherine Bradbury, "Rising Tide in the Labor Market: To What Degree Do Expansions Benefit the Disadvantaged," New England Economic Review, 32 (May/June 2000), 3-33.

5. See, for example, Gøsta Esping-Andersen, The Three Worlds of Welfare Capitalism (Cambridge: Polity Press, 1990).

6. Stephen Nickell and Richard Layard, "Labor Market Institutions and Economic Performance," Handbook of Labor Economics, 3 (1999), 3029-84; Lane Kenworthy, Egalitarian Capitalism (New York: Russell Sage Foundation, 2004), ch. 5.

7. Jonas Pontusson, Inequality and Prosperity: Social Europe vs. Liberal America (Ithaca: Cornell University Press, 2005), ch. 7. In line with Pontusson, Nickell argues that the effects of benefit generosity on unemployment are limited when accompanied by "activation." See Stephen Nickell, "Unemployment and Labor Market Rigidities: Europe versus North America," Journal of Economic Perspectives, 11 (Summer 1997), 55-74. I will return to this point in the sections below.

8. David H. Bradley and John D. Stephens, "Employment Performance in OECD Countries: A Test of Neoliberal and Institutionalist Hypotheses," Comparative Political Studies, 40 (December 2007), 1486-510.

9. The terms welfare-to-work and workfare are often employed to describe a particular aspect of activation policies commonly identified with the "Anglo-Saxon" model. In this section, I use it to encompass a more general set of policies.

10. Frank Vandenbroucke, "The Active Welfare State: A Social-Democratic Ambition for Europe," The Policy Network Journal, 1 (2001), 4.

11. Jane Jenson and Denis Saint-Martin, "New Routes to Social Cohesion? Citizenship and the Social Investment State," The Canadian Journal of Sociology, 28 (Winter 2003), 86.

12. Nathalie Morel, Bruno Palier, and Joakim Palme, "Beyond the Welfare State as We Knew It?" in Nathalie Morel, Bruno Palier, and Joakim Palme, eds., Towards a Social Investment Welfare State? (Bristol: The Policy Press, 2012), 9.

13. See Morel et al. and Jane Jenson, "Redesigning Citizenship Regimes after Neoliberalism," in Morel et al., eds., 2012.

14. Morel et al., 9-10.

15. Werner Eichhorst and Regina Konle-Seidl, "Contingent Convergence: A Comparative Analysis of Activation Policies,” IZA Discussion Article No. 3905 (2008), 3.

16. Ibid., 6.

17. Ibid.

18. Esping-Andersen, 1990, 22.

19. Desmond King, Actively Seeking Wbrk? (Chicago: The University of Chicago Press, 1995), xiii.

20. See Gøsta Esping-Andersen, "Politics without Class," in Herbert Kitschelt, Peter Lange, Gary Marks, and John D. Stephens, eds., Continuity and Change in Contemporary Capitalism (New York: Cambridge University Press, 1999); and David Rueda, Social Democracy Inside Out: Partisanship and Labor Market Policy in Industrialized Democracies (Oxford: Oxford University Press, 2007).

21. On the relationship between new social risks and the welfare state, see, for example, Peter Taylor-Gooby, New Risks, New Welfare (Oxford: Oxford University Press, 2004).

22. See, for example, the contributions in Paul Pierson, ed., The New Politics of the Welfare State (Oxford: Oxford University Press, 2001).

23. See Bernhard Ebbinghaus, Reforming Early Retirement in Europe, Japan and the USA (Oxford: Oxford University Press, 2006).

24. Paul Pierson, "Post-Industrial Pressures on the Mature Welfare States," in Pierson, ed., 2001.

25. Richard Clayton and Jonas Pontusson, "Welfare State Retrenchment Revisited," Wbrld Politics, 51 (October 1998), 70. This point is particularly important when trying to capture conditionality, which can reflect a reduction in supply in spite of an increasing or stable demand for benefits.

26. See, for example, Torben Iversen and Thomas R. Cusack, "The Causes of Welfare State Expansion: Deindustrialization or Globalization?” World Politics, 52 (April 2000), 313-49.

27. The harmonized unemployment rate captures the number of unemployed persons as a percentage of the civilian labor force using definitions of employment and unemployment that conform with ILO guidelines (see OECD or Eurostat documentation). 
28. Unemployment benefits include all public cash expenditures to the unemployed, redundancy payments out of the public budget, as well as some early-retirement "pension" expenditure to unemployed beneficiaries before they reach the standard pensionable age. The measure is provided in the OECD Social Expenditure Database.

29. Active measures include spending on public employment services and administration, labor market training, school-to-work youth programs, and employment programs for the disabled. The measure is provided in the OECD Social Expenditure Database.

30. Korpi and Palme, for example, analyze net replacement rates in the public insurance systems for sickness, disability, and unemployment for eighteen OECD countries. They find that the welfare state underwent a change between the 1980s and 1990s. They conclude "that the long gradual increase in average benefit levels characterizing developments up to the mid-1970s has not only stopped but turned into a reverse" (Korpi and Palme, 2003, 445).

31. An alternative measure for the demanding side of workfare can be explored by examining the unemployment insurance replacement rates calculated in Lyle Scruggs's "Welfare State Entitlements Data Set" (2004, Version 1.1). These represent the ratio of net unemployment insurance benefit to net income for individuals earning the average production worker wage (who are single or have no dependents). Keeping in mind that this article's data begin in 1985 and Scruggs' data end in 2002 and that some important countries in Table 1 are missing from the replacement rate sample (Greece, Luxembourg, Portugal, and Spain), the relationship between these alternative measures is strong. Higher levels of unemployment benefit generosity are correlated with higher replacement rates in the Scruggs's data. Moreover, if we were to analyze temporal change for replacement rates in a similar way to that in Table 2, the results would corroborate this article's argument. Scruggs's replacement rates experience a significant yearly decline.

32. In some cases, some of the yearly data for generosity or unemployment are missing in the 3-year periods in the figures. When this is the case, the average is calculated from the available years. Calculations are available from the author.

33. Note that time is now measured as period averages, rather than years. For the twelve countries in the analysis, we have data for all periods for all countries except Germany (missing both generosity data and harmonized unemployment for the mid-1980s) and Luxembourg (missing passive labor market policy generosity data for the 2000 period).

34. This finding is confirmed in the more systematic analysis in David Rueda, "The Welfare State in Times of Crisis," in Larry Bartels, Nancy Bermeo, and Jonas Pontusson, eds., Coping with Crisis: Government Reactions to the Great Recession (New York: Russell Sage Foundation, 2012). It is also consistent with some of the findings in Bradley and Stephens, as mentioned above, and Pontusson, which shows that some social market economies perform better than liberal market economies when it comes to limiting unemployment.

35. This time, I estimate the effects of labor market policy generosity on market income inequality while controlling for country fixed effects. Note that time is again measured as period averages, rather than years. Due to the availability of inequality data, we now lose five observations for the twelve countries in the decommodifying welfare state analysis (Finland 1990, Germany mi-1980s, Luxembourg 1990, Norway 1990, and Portugal mid-1980s). We again lose one observation in the workfare state analysis (Luxembourg 2000).

36. Gini coefficients range from 0 to 1 (with higher values signifying more unequal distributions). See OECD, Growing Unequal? (Paris: OECD, 2008) and particularly Annex 1.A1 for a description of sources and definitions.

37. See, for example, Vincent A. Mahler and David K. Jesuit, "Fiscal Redistribution in the Developed Countries: New Insights from the Luxembourg Income Study," Socioeconomic Review, 4 (September 2006), 483-511.

38. It is important to note that the availability of our data limits our analysis of the effects of the decommodifying welfare state to the years after 1985. One could speculate that including observations from earlier periods (particularly pre-1970s, the Golden Age of Social Democracy) would make the positive effects of generosity even stronger.

39. See Giuliano Bonoli, “Active Labour Market Policy and Social Investment," in Morel et al., eds., 2012. For more supporting evidence, see the country analyses in Werner Eichhorst, Otto Kaufmann, and Regina Konle-Seidl, eds., Bringing the Jobless into Work? (New York: Springer, 2008). But see Moira Nelson and John D. Stephens, "Do Social Investment Policies Produce More and Better Jobs?" in Morel et al., eds., 2012, who argue that social investment policies have been successful in promoting employment in knowledgeintensive services.

40. The work of Tony Atkinson (see, for example, Tony Atkinson, "Bringing Income Distribution in From the Cold," The Economic Journal, 107 (1997), 306) is perhaps the landmark for this approach. But see also 
Walter Korpi and Joakim Palme, "The Paradox of Redistribution and Strategies of Equality," American Sociological Review, 63 (October 1998), 661-87; Pontusson; and Lane Kenworthy, Progress for the Poor (Oxford: Oxford University Press, 2011), ch. 6.

41. See Korpi and Palme, 1998, for a similar approach. As with market income, the Gini coefficients are taken from the OECD Data on Income Distribution.

42. I estimate the effects of harmonized unemployment rates on redistribution while controlling for country fixed effects. Once again, time is measured as periods, not years. While the availability of inequality data limited our analysis of the decommodifying welfare state to thirty-one observations in Table 4, we are now able to add six additional observations from the mid-1970s (Canada, Finland, Netherlands, Sweden, the UK, and the USA). These are averages for 1974-1976 (corresponding to mid-1970s inequality data from the OECD). They bring the total number of observations for the decommodifying welfare state period in Table 5 to thirty-seven.

43. For evidence showing that a general negative relationship between welfare state generosity and disposable income inequality exists, see David H. Bradley, Evelyne Huber, Stephanie Moller, François Nielsen, and John D. Stephens, "Distribution and Redistribution in Post-industrial Democracies," Wbrld Politics, 55 (January 2003), 193-228. Their analysis does not focus on within-country variation and, more importantly, makes no distinction between the two periods of welfare policy.

44. Sidney Verba, Norman Nie, and Jae-On Kim, Participation and Political Equality (New York: Cambridge University Press, 1978); Steven Rosenstone and John Mark Hansen, Mobilization, Participation and Democracy in America (New York: Macmillan, 1993).

45. Hans-Georg Betz, Radical Right-Wing Populism in Western Europe (New York: St. Martin's Press, 1994).

46. For a review, see Mark Lichbach, "An Evaluation of 'Does Economic Inequality Breed Political Conflict?' Studies,” World Politics, 41 (1989), 431-70.

47. Larry Bartels, Unequal Democracy: The Political Economy of the New Gilded Age (Princeton: Princeton University Press, 2008).

48. Jacob S. Hacker and Paul Pierson, Winner-Take-All Politics (New York: Simon and Schuster, 2011).

49. See Rueda, 2012 and David Rueda, "Dualization, Crisis and the Welfare State," Socio-Economic Review, 12 (April 2014), 381-407. 